BOGDAN SZCZEPANKOWSKI

Spoteczna Akademia Nauk

w Warszawie

\title{
Z HISTORII POLSKIEJ SURDOPEDAGOGIKI - TRUDNE POCZĄTKI
}

AbSTRACt. Szczepankowski Bogdan, Z historii polskiej surdopedagogiki - trudne poczatki [History of Polish Deaf Pedagogy - the Difficult Start]. Studia Edukacyjne nr 45, 2017, Poznań 2017, pp. 95-106. Adam Mickiewicz University Press. ISSN 1233-6688. DOI: 10.14746/ se.2017.45.8

The Institute for the Deaf-mute in Warsaw, established in 1817 by Father Jakub Falkowski, is commonly considered to be the first school for deaf-mute children in Poland. However, similar actions had been taken three times earlier: in 1803 in Romanow, Volhynia, in 1804 in Vilnius, and in 1809 in Warsaw. Unfortunately, those activities did not generate the expected effects. The article recalls those unsuccessful attempts of establishing the first schools for deaf children.

Key words: history, education, deaf-mute child

Początki polskiej surdopedagogiki - zbiorowego kształcenia i wychowania dzieci niesłyszących - datuje się zwykle od roku 1817, kiedy w Warszawie powstał Instytut Głuchoniemych, założony przez o. Jakuba Falkowskiego' Tymczasem, warto przypomnieć, że wcześniej trzykrotnie podejmowano próby utworzenia podobnych szkół, choć ich skutki dla polskiej surdopedagogiki nie były w pełni udane.

\section{Pierwsza próba - Instytut dla Glucho-niemych ${ }^{2}$ w Romanowie (1803)}

Pierwsza próba powołania placówki kształcącej głuchonieme dzieci miała miejsce w 1803 roku na Wołyniu. Inicjatywa założenia pierwszej takiej szkoły,

${ }^{1}$ O. Jakub Falkowski (1775-1848), pijar, założyciel i pierwszy rektor warszawskiego Instytutu Głuchoniemych.

2 Pisownia oryginalna. 
pod dostojną nazwą „Instytutu dla Głucho-niemych” ${ }^{3}$, była osobistym pomysłem polskiego arystokraty hrabiego Józefa Augusta Ilińskiego ${ }^{4}$. Będąc człowiekiem niezwykle zamożnym, postanowił w swoim majątku w Romanowie ufundować szkołę dla dzieci głuchych. W preambule zapisu fundacyjnego ${ }^{5}$ napisał m.in.:

Powinnością jest każdego czułego człowieka wspierać nieszczęśliwych. Z tego powodu ja, hrabia August Iliński (...) poświęcam część mego maiątku na zaprowadzenie Instytutu dla głucho-niemych w miasteczku mojem Romanowie, w Gubernii Wołyńskiey w Powiecie Nowogrod Wołyńskim leżącem, w tym zamiarze, aby ci biedni mogli znaydować w nim ulgę nieszczęśliwego swego losu, i środki do nadgrodzenia tego, co im przyrodzenie ubliżyło.

W dalszej części tekstu została dokładnie opisana struktura i działalność projektowanej placówki. Zapis fundacyjny hr. Iliński złożył 17 września 1803 roku w Równem na ręce Tadeusza Czackiego ${ }^{6}$, który wówczas był wizytatorem nadzwyczajnym szkół w guberni wołyńskiej, kijowskiej i podolskiej. Tadeusz Czacki konsultował projekt Ilińskiego z Hugonem Kołłątajem ${ }^{8}$, w drodze licznej korespondencji ${ }^{9}$ (w latach 1803-1804 wymieniono łącznie 9 listów). Zarówno Tadeusz Czacki, jak i Hugo Kołłątaj krytycznie oceniali ten zamiar, uważając, że projekt nie gwarantuje pozytywnych wyników kształcenia. Hrabia Iliński był jednak nieustępliwy. W 1805 roku dotarł ze swoim zapisem fundacyjnym aż do ówczesnego cara Rosji Aleksandra I i uzyskał jego wsparcie. Car ten osobiście podpisał datowaną na 27 maja 1805 roku odpowiedź do hr. Ilińskiego ${ }^{10}$, w której znalazło się m.in.:

${ }^{3}$ W tym okresie zwyczajowo szkoły dla dzieci głuchoniemych w Europie nazywano „instytutami".

${ }^{4}$ Józef August Iliński (1766-1844), poseł, senator, szambelan, pełniący różne funkcje państwowe, był właścicielem dóbr w Romanowie na Żytomierszczyźnie. Kawaler maltański (pełniący w zakonie godności komandora i wielkiego sędziego), odznaczony Orderem Orła Białego. Był jednym z najbogatszych Polaków.

5 A. Iliński, Akt zaprowadzenia Instytutu głucho-niemych w Miasteczku Romanowie, „Dziennik Wileński", 1805, N. IV, s. 68.

${ }^{6}$ Tadeusz Czacki (1765-1813), pedagog, członek Komisji Edukacji Narodowej, współtwórca Konstytucji 3 Maja, współzałożyciel warszawskiego Towarzystwa Przyjaciół Nauk, współtwórca Liceum Krzemienieckiego zwanego Atenami Wotyńskimi (1805).

${ }^{7}$ B. Trębicka-Postrzygacz, Szkoty dla dzieci niestyszacych na ziemiach polskich w latach 18171914, Towarzystwo Naukowe KUL, Lublin 2011, s. 79.

${ }^{8}$ Hugo Kołłątaj (1750-1812), polski polityk oświatowy, ksiądz, doktor filozofii, prawa i teologii, rektor Akademii Krakowskiej (1782-1786), twórca zespołu publicystów znanego pod nazwą Kuźnicy Kotłątajowskiej, współtwórca Konstytucji 3 Maja, współpracownik Komisji Edukacji Narodowej, współzałożyciel z Tadeuszem Czackim Liceum Krzemienieckiego (1805), członek rzeczywisty Towarzystwa Warszawskiego Przyjaciół Nauk (1809-1812).

${ }^{9}$ E. Nurowski, Surdopedagogika polska. Zarys historyczny, Warszawa 1983, s. 24.

${ }^{10}$ A. Iliński, Akt zaprowadzenia Instytutu, s. 67. 
Dzieło to ludzkości nayżywszem jest dla mnie ukontentowaniem, a czyniąc zadość jego chęciom, potwierdzam urządzenie, któreś WPan uczynił na pomoc i wsparcie z urodzenia nieszczęśliwych. Obowiązałem przeto Ministra oświecenia, aby mię uwiadomił, kiedy determinowane przez WPana urządzenie przyidzie do skutku, a to dla okazania Urządzicielowi szczególnych moich względów.

W sytuacji tej hr. Iliński rozpoczął pierwsze próby w celu uruchomienia projektowanej placówki, która z założenia miała być szkołą z internatem przeznaczoną dla 50 uczniów i uczennic głuchoniemych w wieku od 8 do 14 lat. Koszty utrzymania dzieci miał ponosić fundator, czyli hr. Iliński (na ten cel $\mathrm{w}$ zapisie fundacyjnym przeznaczył 1 milion złotych polskich $\left.{ }^{11}\right)$. W tym czasie w ówczesnym zaborze rosyjskim, podobnie jak w całej Rosji, nie było ani jednej placówki kształcącej niesłyszące dzieci i zapewne dlatego łatwiej było pozyskać wsparcie cara Aleksandra I dla tej idei. Najbardziej znane szkoły w tym czasie, to paryski Instytut Głuchoniemych, założony w 1770 roku przez ks. Charlesa de l'Épée, kierowany wówczas przez ks. Rocha Sicarda oraz Instytut Głuchoniemych w Wiedniu, powstały w 1779 roku, którego dyrektorem był wtedy Joseph May. Hr. Iliński nie zamierzał jednak korzystać z doświadczeń swych poprzedników. Projektowana przez niego, wzorcowa jego zdaniem, placówka nawet współcześnie mogłaby wydawać się nadmiernie przeładowana programowo i niemożliwa do pełnej realizacji. Ostateczny projekt Instytutu podpisany został przez fundatora 19 marca 1805 roku i opublikowany w „Dzienniku Wileńskim” nr 4 z 1805 roku.

Zgodnie z aktem fundacyjnym, do Instytutu miały być przyjmowane głuchonieme dzieci w wieku od 8 do 14 lat, ze świadectwem chrztu (a więc wiary chrześcijańskiej) oraz ze świadectwem zdrowia. Szkoła miała być sześcioletnia, ale na trzech poziomach nauczania. Wszyscy mieli zaczynać od poziomu pierwszego, najwyższego przez 6 miesięcy. Potem nastąpić miała selekcja i przeniesienie słabszych uczniów na drugi lub trzeci poziom - drugi miał być dla uczniów uzdolnionych w zakresie sztuk pięknych, trzeci dla tych, którzy ani nie mieli szans utrzymania się na pierwszym poziomie, ani nie wykazywali zdolności artystycznych. Na drugim poziomie uczniowie mieli uczyć się architektury, rysunku, malarstwa, snycerstwa, sztukaterii, złotnictwa i innych. Trzeci poziom - najniższy - to nauka zawodów rzemieślniczych, m.in. takich jak stolarstwo, tapicerstwo, sukiennictwo, siodlarstwo itp. Dla uczniów najzdolniejszych, którzy mieli zostać na pierwszym poziomie, przewidziano naukę mowy, pisania, języków (rosyjskiego, polskiego, niemieckiego, francuskiego, włoskiego i łaciny), arytmetyki, religii i rysunków ${ }^{12}$. Plany

${ }^{11}$ H. Okopiński, Zarys dziejów nauczania głuchoniemych, Warszawa 1964, s. 94.

12 A. Kierzek, Instytut dla głuchoniemych w Romanowie - pierwszy ośrodek tego typu na ziemiach polskich, Otolaryngologia, 2012, 11(4), s. 152. 
te były wyjątkowo ambitne i zapewne dlatego zostały negatywnie ocenione przez specjalistów pedagogów.

Jeszcze w 1805 roku rozpoczęły się przygotowania do budowy siedziby dla planowanej placówki w Romanowie. Hr. Iliński zamówił projekt budynku u francuskiego architekta Jean-François Thomasa de Thomon ${ }^{13}$, który od 1799 roku mieszkał stale $w$ Petersburgu ${ }^{14}$. Budowa i urządzanie Instytutu zakończyły się w roku 1808 i w tym samym roku rozpoczęła się rzeczywista działalność tej placówki. Fundator zastrzegł sobie prawo powoływania dyrektora i nauczycieli. Hr. Iliński pragnął pozyskać na stanowisko dyrektora Instytutu wybitnego specjalistę od nauczania głuchoniemych Ernsta Adolfa Eschke ${ }^{15} \mathrm{z}$ Instytutu w Berlinie, $\mathrm{z}$ którym prowadził korespondencję na ten temat. Eschke jednak odmówił ${ }^{16}$. Ostatecznie dyrektorem nowo powstającej placówki, z mianowania hr. Ilińskiego, został Johann Franz Gamperle (urodzony w Pradze ok. 1755 r. zmarły w 1830) ${ }^{17}$. Był on synem wybitnego praskiego prawnika o tych samych imionach (przez co często mylono go $\mathrm{z}$ ojcem $)^{18}$. Jego narodowość była określona jako der Deutscher-Böhme, czyli Czech pochodzenia niemieckiego ${ }^{19}$. Ukończył studia prawnicze na Uniwersytecie Karola Ferdynanda w Pradze i tam w 1794 roku uzyskał doktorat z prawa. Był adwokatem i pracownikiem urzędu podatkowego w Pradze. Być może po uzyskaniu doktoratu był również adiunktem na Uniwersytecie Karola Ferdynanda w Pradze. W latach 1804-1807 został zaangażowany do pracy na nowo powstałym Uniwersytecie w Charkowie jako profesor adiunkt, prowadząc wykłady z policystyki ${ }^{20}$ i nauki o państwie (w języku

${ }^{13}$ Jean-François Thomas de Thomon (1760-1813), francuski architekt neoklasycystyczny, pracował w Petersburgu w latach 1799-1813. Był m.in. autorem projektów Budynku Giełdy w Sankt Petersburgu, Teatru Odessa i wielu innych budowli i pomników.

${ }^{14}$ W.M. Szewczenko, Winikniennia i rozwitok w Ukraini spiecialnich szkit dla gtuchonimich u drugij połowini XIX - początku XX stolittia, Kijów 2010, s. 38.

${ }_{15}$ Ernst Adolf Eschke (1766-1811), założyciel i dyrektor Królewskiego Instytutu Głuchoniemych w Berlinie, autor kilku książek o nauczaniu głuchych.

${ }^{16}$ H. Okopiński, Zarys dziejów, s. 100.

17 W niektórych współczesnych publikacjach (S. Dziedzic, A. Kierzek, E. Nurowski, B. Trębicka-Postrzygacz) występuje zapis nazwiska "de Gamperle”, jednak w XVIII i XIX-wiecznych wykazach prawników wyraz "de" oznaczający szlacheckie pochodzenie przy nazwisku Gamperle nie występuje, chociaż pojawia się przy innych nazwiskach. Również w źródłowym raporcie Michała Ściborskiego (patrz dalej) "de" nie występuje. Tym samym pisownia „de Gamperle” nie znajduje uzasadnienia.

${ }^{18}$ Johann Franz Gamperle (1730-1800), urodzony w Kodaniu w Królestwie Czeskim, absolwent wydziału prawa Uniwersytetu Karola Ferdynanda w Pradze (1762), doktor praw (1765), radca i prokurator królewski, przez blisko 40 lat piastował w Pradze różne wysokie stanowiska na usługach dworu cesarskiego, w 1783 r. osobiście wyróżniony i nagrodzony przez cesarza Józefa II.

${ }^{19}$ Mógł być również pochodzenia żydowskiego, bo na s. 99 książki J. Boháčka i in. Soupis židowských rodin w Čechach z roku 1793 (t. 2, s. 99) jest wymieniona rodzina Johanna Franza Gamperle.

${ }^{20}$ Policystyka była to nauka o regulowaniu całości życia społecznego przez monarchę, rozwijająca się szczególnie w państwach niemieckich w XVII i XVIII wieku. 
łacińskim). W 1807 roku, w wyniku ostrego konfliktu z profesorem historii Francuzem Antoine Jeudy DuGourem musiał opuścić uniwersytet. Wtedy przyjął posadę u hr. Ilińskiego jako dyrektor nowo powstającego Instytutu Głuchoniemych w Romanowie, gdzie przebywał do 1811 roku. Niestety, nie miał jednak żadnego przygotowania $\mathrm{z}$ dziedziny nauczania głuchoniemych.

Jako wykładowca języka francuskiego i literatury zatrudniony został Jacob Raymond de Mousseaux, natomiast Ferdynand Oszmieniec nauczyciel szkół publicznych pracował jako sekretarz Instytutu i nauczał geografii, historii oraz arytmetyki. We wrześniu 1808 roku Gamperle i de Mousseaux przygotowali $w$ języku francuskim i podpisali raport dotyczący organizacji Instytutu oraz jego kadry naukowej, skierowany do ówczesnego rosyjskiego ministra oświecenia - hr. Piotra Zawadowskiego. W raporcie przedstawiono tak optymistyczne dane, że mogły one budzić wątpliwości co do ich rzetelności ${ }^{21}$. Podano m.in., że w pierwszym roku nauki głuchoniemi uczniowie będą uczyć się 34 przedmiotów (w tym 5 języków obcych) oraz że oddano do użytku nowe budynki (co było prawdą), w których znajdują się 3 wielkie sale, 36 pokoi, a ponadto ogromny ogród i plac do nauki gospodarstwa wiejskiego, a uczniowie mogą korzystać $\mathrm{z}$ biblioteki oraz innych pomocy naukowych znajdujących się w kolekcjach hr. Ilińskiego. Nadmieniono także, że wychowankowie są dobrze żywieni i schludnie ubrani, a także mają stałego, czuwającego nad ich zdrowiem lekarza. W raporcie znalazł się również imienny wykaz 32 osób zatrudnionych $\mathrm{w}$ szkole, w tym 22 nauczycieli ${ }^{22}$. Do raportu dołączono alfabety palcowe polski i rosyjski ${ }^{23}$, najprawdopodobniej opracowane przez ks. Anzelma Zygmunta w 1805 i 1806 roku, a pozyskane z Uniwersytetu Wileńskiego lub Zgromadzenia Księży Misjonarzy Wincentego á Paulo.

Nic więc dziwnego, że ten „hurraoptymistyczny” raport spowodował cztery miesiące po jego złożeniu pojawienie się w Instytucie wizytatora, w osobie nauczyciela matematyki z Liceum Krzemienieckiego - Michała Ściborskiego. Podczas wizytacji okazało się, że w Instytucie przebywało tylko 12 uczniów, z których jedynie trzech było w stanie czymkolwiek się pochwalić, jak np. znajomość tzw. „daktylonomii”, czyli alfabetu palcowego, za pomocą którego byli w stanie przekazać 104 wyrazy w języku niemieckim, francuskim i rosyjskim, jednak bez rozumienia treści tych wyrazów. Spośród wymienionych w wykazie 22 nauczycieli było tylko trzech: J.F. Gamperle, J.R. de Mousseaux i F. Oszmieniec (kolejnych trzech będących w Romanowie nie pracowało w Instytucie,

${ }^{21}$ Oceniający po latach w swych pracach ów raport Henryk Okopiński i Stefan Dziedzic napisali: „nie wiadomo, co w tym raporcie należałoby więcej podziwiać: fantazję, naiwność czy bezczelność" (Okopiński, 1964, s. 98) oraz "splot ignorancji z dziecinną fantazją lub szalbierstwem" (Dziedzic, 1977, s. 528).

22 A. Manczarski, Instytut Głuchoniemych w Romanowie na Wołyniu, Szkoła Specjalna, 1935/1936, XII, s. 116-118.

${ }^{23}$ H. Okopiński, Zarys dziejów, s. 97. 
lecz w pałacu Ilińskiego, pełniąc tam funkcje aptekarza, koniuszego i ogrodnika) $)^{24}$. Ściborski zarzucił również niekompetencję zarówno dyrektorowi, jak i nauczycielom, stwierdzając, że nie wiedzą oni jak uczyć głuchonieme dzieci, że nie korzystają z dzieł i doświadczeń specjalistów, takich jak John Wallis, Jan Conrad Ammann, Jacob Pereira, Charles de l'Épée, czy Roch Sicard. Zwrócił także uwagę na zbyt wysokie wynagrodzenia nauczycieli, wypłacane także tym, którzy nie byli obecni w Instytucie. W raporcie Ściborskiego, złożonym w marcu 1809 roku, znalazło się również stwierdzenie dotyczące zbyt dużej liczby zarówno nauczycieli, jak i przedmiotów nauczania ${ }^{25}$.

Liczba uczniów Instytutu nie osiągnęła nigdy planowanych 50 dzieci. W 1809 roku było ich 17 (14 chłopców i 3 dziewczynki), w 1812 roku, kiedy dyrektorem był Bartłomiej Przeradzki, najwięcej, bo 22 (17 chłopców i 5 dziewcząt), zaś w 1813 roku tylko 11 uczniów, z którymi pracowało trzech nauczycie$\mathrm{li}^{26}$. Poziom nauczania był niezwykle niski. Zaledwie trzech uczniów zdobyło umiejętność przepisywania tekstów w języku niemieckim, francuskim i rosyjskim, jednak bez ich rozumienia. Wiedza arytmetyczna kończyła się u nich na poziomie działań na liczbach dwucyfrowych. Reszta uczniów nie opanowała nawet alfabetu palcowego.

W kolejnych latach (1811 i 1812) placówkę wizytował sam Tadeusz Czacki. W swych raportach potwierdzał, że wyniki nauczania są niemal żadne, o czym każdorazowo informował mieszkającego wówczas w Petersburgu fundatora - hr. Ilińskiego ${ }^{27}$. Zdawał on sobie sprawę z nieudolności kierownictwa placówki i chciał tę sytuację zmienić. Próbował ponownie pozyskać na miejsce odchodzącego dyrektora Gamperle ówczesnego dyrektora Instytutu Głuchoniemych w Berlinie - Ernsta Adolfa Eschke, jednak ten ostatecznie odmówił, tym razem także ze względu na stan zdrowia (wkrótce zmarł) ${ }^{28}$. Ostatecznie dyrektorem Instytutu został mianowany Bartłomiej Przeradzki, jednak nie doprowadziło to do znaczących zmian na lepsze. Placówka stopniowo zaczęła podupadać. Władze oświatowe dostrzegając tę sytuację, zaczęły kierować do Instytutu także dzieci opuszczone czy zaniedbane, lecz nie głuchonieme, traktując Instytut jak zwykły przytułek ${ }^{29}$. Wprawdzie Instytut funkcjonował formalnie jeszcze około 20 lat, jednak $w$ historii polskiej surdopedagogiki nie znalazł dla siebie godnego miejsca, mimo szczytnych idei, które przyświecały hr. Józefowi Augustowi Ilińskiemu.

\footnotetext{
${ }^{24}$ Tamże, s. 98-99.

25 Tamże, s. 100.

${ }^{26}$ W.M. Szewczenko, Winikniennia, s. 43.

27 Tamże, s. 44.

28 A. Kierzek, Instytut, s. 153.

${ }^{29}$ W.M. Szewczenko, Winikniennia, s. 43.
} 


\section{Druga próba \\ - inicjatywa uruchomienia instytutu głuchoniemych w Wilnie (1804)}

Druga nieudana próba uruchomienia placówki kształcenia głuchoniemych dzieci zaczęła się w 1804 roku. Kiedy ówczesny biskup wileński i inflancki Jan Nepomucen Korwin-Kossakowski przebywał na leczeniu w Wiedniu, odwiedził wówczas istniejący tam od 25 lat słynny Instytut Głuchoniemych. Nie tylko zachwycił się rezultatami kształcenia, ale stwierdziwszy, że przy Instytucie istnieje roczne seminarium dla nauczycieli dzieci głuchoniemych (jedyne wówczas nie tylko w Europie, ale i na świecie), postanowił skorzystać z możliwości skierowania kogoś na studia w seminarium, a w przyszłości otworzyć w Wilnie instytut głuchoniemych ${ }^{30}$. Po powrocie do Wilna biskup Kossakowski nawiązał kontakt ze Zgromadzeniem Księży Misjonarzy św. Wincentego á Paulo, którego członkowie prowadzili w Wilnie działalność edukacyjną, w tym wyższe seminarium duchowne. Znalazł tam ks. Anzelma Zygmunta, Polaka, profesora tegoż seminarium (wykładał tam teologię i język niemiecki), który urodzony w 1771 roku w Reszlu ${ }^{31}$, kończył niemiecką szkołę i władał swobodnie tym językiem. W lipcu 1804 roku biskup Kossakowski, na własny koszt, wysłał ks. Anzelma Zygmunta na studia surdopedagogiczne do Wiednia ${ }^{32}$.

Ksiądz Anzelm Zygmunt po roku ukończył seminarium wiedeńskie, a w sierpniu 1805 roku zdał odpowiedni egzamin publiczny, uzyskując dyplom uprawniający go do nauczania głuchych i powrócił do Wilna. Stał się pierwszym polskim wykwalifikowanym surdopedagogiem, ale także pierwszym takim specjalistą na terenie całej Rosji.

Wkrótce z pomocą biskupa Kossakowskiego zostały wszczęte starania w celu uruchomienia szkoły dla głuchoniemych dzieci. Ks. Anzelm Zygmunt rozpoczął indywidualne nauczanie głuchoniemego 10-letniego chłopca - Janka Rajeckiego i na podstawie alfabetu palcowego stosowanego w Wiedniu opracował polski alfabet palcowy ${ }^{33}$. Aby pozyskać wsparcie Uniwersytetu Wileńskiego, alfabet ten został wydrukowany w drukarni Zgromadzenia Księży Misjonarzy i uroczyście wręczony władzom uczelni na sesji Rady Uniwersytetu Wileńskiego 15 maja 1806 roku $^{34}$.

${ }^{30}$ E. Nurowski, Surdopedagogika, s. 23.

${ }^{31}$ Reszel po pierwszym rozbiorze Polski w 1772 r. został przyłączony do Prus.

32 B. Szczepankowski, Ksiądz Anzelm Zygmunt - pierwszy surdopedagog polski, Szkoła Specjalna, 2007, 5, s. 342 .

${ }^{33}$ Być może był to ten sam alfabet palcowy, który kilkanaście lat później wykorzystywał ks. Jakub Falkowski w warszawskim Instytucie Głuchoniemych.

${ }^{34}$ Poinformowała o tym „Gazeta Literacka Wileńska” nr XXVIII z 14 lipca 1806 r. 
Oficjalne starania o uruchomienie szkoły zgłoszono w Petersburgu, gdzie jednak nastąpił znaczący zwrot $w$ projektowanych działaniach. $W$ tym bowiem czasie na dworze cesarzowej Marii Fiodorowny ${ }^{35}$ w Pawłowsku, pod Petersburgiem, przebywał na stałe głuchoniemy chłopiec - syn dowódcy garnizonu pawłowskiego. Kiedy na dwór carski dotarła wiadomość, że w Wilnie znajduje się wykwalifikowany nauczyciel głuchoniemych, cesarzowa postanowiła uruchomić taką szkołę właśnie w Pawłowsku, gdzie znalazło się jeszcze kilkoro głuchoniemych dzieci, a kierownikiem i nauczycielem tej szkoły uczyniła właśnie ks. Anzelma Zygmunta. Szkoła ta została otwarta 2 grudnia 1806 roku, a zlokalizowano ją w sąsiadującej z pałacem twierdzy Marienthal, siedzibie pawłowskiego garnizonu. Ks. Anzelm Zygmunt musiał więc pozostawić planowaną dla polskich dzieci szkołę w Wilnie, a zająć się dziećmi rosyjskimi, chociaż otrzymał zgodę na zabranie ze sobą do Pawłowska swego wileńskiego ucznia Janka Rajeckiego ${ }^{36}$. Odmienne od polskiego pismo rosyjskie spowodowało, że ks. Anzelm Zygmunt w 1806 roku opracował także rosyjski alfabet palcowy (który w Rosji stosowany jest do dzisiaj ${ }^{37}$ ).

Ks. Anzelm Zygmunt przebywał w Pawłowsku 4 lata, prowadząc z sukcesami szkołę dla głuchoniemych dzieci. Cesarzowa Maria Fiodorowna otoczyła ją osobistą opieką, często bywała na lekcjach, a na zakończenie każdego roku szkolnego w dowód swego uznania obdarowywała ks. Anzelma Zygmunta pierścieniem z brylantem. Ponieważ jednak tamtejszy klimat nie służył jego zdrowiu, mimo przeniesienia szkoły w 1810 roku do Petersburga, musiał zrezygnować z pracy i powrócić do Wilna. Na pożegnanie otrzymał kolejny pierścień - znakomite świadectwo pracy, a car Aleksander I odznaczył go Orderem św. Włodzimierza IV klasy ${ }^{38}$.

Po powrocie do Wilna starania o uruchomienie szkoły dla dzieci głuchoniemych zostały wznowione. Ponieważ biskup Kossakowski zmarł w 1808 roku (zostawiając $\mathrm{w}$ testamencie legat dla planowanej szkoły), przygotowaniami zajęło się Zgromadzenie Księży Misjonarzy, którego członkiem był ks. Anzelm Zygmunt. Dotację na ten cel przeznaczył również Uniwersytet Wileński. 24 stycznia 1811 roku Zgromadzenie wystosowało do rektora Uniwersytetu list dziękczynny, w którym również zobowiązało się do urucho-

${ }^{35}$ Maria Fiodorowna (1759-1828), Niemka z pochodzenia, urodzona w Szczecinie jako Sophia Dorotea von Württemberg, siostrzenica pruskiego króla Fryderyka II była matką ówczesnego cara Aleksandra I, a od $1801 \mathrm{r}$. cesarzową-wdową po zamordowanym carze Pawle I i mieszkała w letnim pałacu w Pawłowsku, $25 \mathrm{~km}$ od centrum Petersburga.

${ }^{36}$ H.G. Williams, P. Fyodorova, The origins of the St. Petersburg Institute for the Deaf, [w:] Looking Back. A Reader of the History of Deaf Communities and their Sign Languages, Hamburg 1993, s. 300 .

${ }^{37}$ B. Szczepankowski, Ksiądz, s. 344.

${ }^{38}$ A. Wolfgang, Rys historyczny usitowań w uczeniu głuchoniemych i zakładów na ten cel przeznaczonych, Józef Zawadzki własnym nakładem, Wilno 1830, s. 141. 
mienia i prowadzenia szkoły dla głuchoniemych dzieci, a także zobowiązało się do utrzymywania w przyszłości dwóch najbiedniejszych uczniów. List podpisał wizytator Zgromadzenia ks. Andrzej Pohl, prokurat ks. Józafat Lawdański, przełożony Domu Misjonarzy ks. Józef Stankonowicz oraz oczywiście ks. Anzelm Zygmunt, przy nazwisku którego dodano „missyonarz, profesor głuchoniemych i kawaler orderu Św. Włodzimierza IV klasy". Do listu dołączony został, datowany na 31 stycznia 1811 roku, program nauczania trzyletniej szkoły: „Rys planu nauk i edukacyi głuchoniemych w mającym się założyć instytucie zrobiony na żądanie Rektora Uniwersytetu". Program ten podpisał ks. Anzelm Zygmunt ${ }^{39}$. Wytypowana została też siedziba placówki w budynku zlikwidowanej Parafii św. Józefa i Nikodema należącej do Zgromadzenia, który wymagał jednak kapitalnego remontu. Wykorzystano na ten cel środki ofiarowane przez Uniwersytet (zapisany legat biskupa Kossakowskiego zawłaszczyli spadkobiercy), następnie środki własne Zgromadzenia, jednak remontu ze względu na zbyt wysokie koszty nie udało się dokończyć. Wydarzenia 1812 roku (dwukrotny przemarsz wojsk napoleońskich przez Wilno praktycznie spustoszył miasto) spowodowały, że szkoła dla głuchoniemych dzieci nie powstała (budynek probostwa został zajęty na szpital wojskowy oraz magazyn leków i środków opatrunkowych).

Ks. Anzelm Zygmunt pozostał do końca życia w Wilnie, pracując nadal jako nauczyciel języka niemieckiego w Seminarium Duchownym Zgromadzenia, jak również prywatnie uczył dwóch głuchoniemych chłopców (jednym z nich był towarzyszący ks. Zygmuntowi w Pawłowsku Janek Rajecki). Sześć lat pełnił funkcję konsultora Prowincji Litewskiej Zgromadzenia, a od 1835 roku był proboszczem parafii przy kościele Księży Misjonarzy pod wezwaniem Wniebowstąpienia Pańskiego na Górze Zbawiciela w Wilnie (kościół stoi do dziś, ale ze względu na zagrożenie budowlane jest zamknięty). Ks. Anzelm Zygmunt przeżywszy 73 lata, zmarł w roku 1844.

\section{Trzecia próba \\ - inicjatywa Towarzystwa Królewskiego Przyjaciół Nauk w Warszawie (1809)}

W grudniu 1809 roku Towarzystwo Królewskie Przyjaciół Nauk w Warszawie $^{40}$ "przez wzgląd na ważność i użyteczność instytutów dla głuchonie-

39 Tamże, s. 143-144.

${ }^{40}$ Towarzystwo Warszawskie Przyjaciół Nauk powstało w 1800 roku. Skupiało wybitnych myślicieli i naukowców, takich jak ks. Stanisław Staszic, Julian Ursyn Niemcewicz, Samuel Bogumił Linde, Stanisław Kostka Potocki, o. Onufry Kopczyński i inni. Członkiem zagranicznym Towarzystwa był m.in. Johann Wolfgang Goethe. Towarzystwo prowadziło badania naukowe 
mych” ogłosiło konkurs i nagrodę „dla tego, ktoby na przyszłość zatrudnił się zaprowadzeniem podobnegoż instytutu w Księstwie Warszawskim, a osobliwie w samej stolicy i okazał pewny dowód pomyślnego skutku swoich usiłowań $\mathrm{w}$ tej mierze" ${ }^{41}$. Interesujące szczególnie jest podłoże tej inicjatywy.

W początkach XIX wieku w Szczuczynie obowiązki nauczyciela, a potem prefekta szkół szczuczyńskich pełnił młody zakonnik, pijar, o. Jakub Falkow$\mathrm{ski}^{42}$. W tym czasie zetknął się po raz pierwszy z głuchoniemym dzieckiem Piotrem Gąssowskim, synem zaprzyjaźnionego z nim zamożnego szlachcica. Przez kilka miesięcy próbował indywidualnej pracy z chłopcem, jednak bez efektu. W 1803 roku, na polecenie władz oświatowych wyjeżdża na ponad rok do Berlina, celem poznania organizacji szkół pruskich. W czasie pobytu próbował zainteresować się możliwościami nauczania głuchych, odwiedzając Królewski Instytut Głuchoniemych ${ }^{43}$, jednak nie mógł wiele skorzystać, bowiem metody pracy z dziećmi nie były chętnie ujawniane ${ }^{44}$. Po powrocie z Berlina o. Falkowski objął posadę nauczyciela w szkole w Drohiczynie, $\mathrm{z}$ zaleceniem wprowadzenia tam wzorca zaobserwowanego $\mathrm{w}$ gimnazjach berlińskich. Wkrótce po powrocie wziął ponownie pod swoją opiekę Piotra Gąssowskiego, zabierając go do Drohiczyna i zajął się jego edukacją. Efektów jednak nie było. Jak sam napisał:

zwyczajem teraz często praktykowanym, jakim się zwykli rządzić niektórzy rodzice i opiekunowie niemowów używałem rozmaitych doradzanych lekarstw na głuchotę i niemotę. Powierzyłem nawet głuchonieme dziecię przechodniemu nieznajomemu sobie, któremu udało się przez wyczyszczenie uszu wzmocnić słuch jednego w okolicy wieśniaka. Lecz gdy ogolenie głowy, kaleczenie uszu, podcinanie języka i inne bolesne środki nie pomogły, a daremne i nieodpowiednie moim dochodom wydatki narażały, zmyśliłem odesłać głuchoniemego jego opiekunom, bez żadnej nadziei, aby przyjść mógł kiedyś do odzyskania mowy ${ }^{45}$.

Wydawać by się mogło, że edukacja Piotra Gąssowskiego nie powiedzie się, jednak w pewnym momencie nastąpił przełom, po którym o. Falkowski napisał:

i wydawało pierwsze polskie czasopismo naukowe - Roczniki Towarzystwa Warszawskiego Przyjaciół Nauk. W 1808 roku Towarzystwo zmieniło nazwę na Towarzystwo Królewskie Przyjaciół Nauk, a jego prezesem został ks. Stanisław Staszic. Po powstaniu listopadowym Towarzystwo zostało rozwiązane przez władze carskie w lipcu 1832 roku.

${ }^{41}$ Roczniki Towarzystwa Przyjaciół Nauk, t. XIII, 1820 r., s. 138.

${ }^{42}$ Zgodnie z tradycją i regułą zakonu, ojcowie pijarzy używają tytułu „ojciec” a nie „ksiądz” (http://www.pijarzy.pl/zakon_i_jego_historia/historia_prowincji_polskiej.html).

${ }^{43}$ W tym okresie w Berlinie działał Królewski Instytut Głuchoniemych, kierowany przez wspomnianego wcześniej Ernsta Adolfa Eschke.

${ }^{44}$ H. Okopiński, Zarys dziejów, s. 103.

${ }^{45} \mathrm{~J}$. Falkowski, O początkach i postępie Instytutu Warszawskiego Gtuchoniemych oraz niektóre jego urządzenia dla wiadomości osób, jakikolwiek związek z Instytutem mieć mogących, Warszawa 1823, s. 20. 
Gdy wychowaniec nabył łatwości wymawiania sylab, dobierane miał wyrazy oznaczające nazwiska przedmiotów pod zmysły podpadających lub czynności jakowych widzialnych. Po nauczeniu się wielu nazwisk rzeczy najpotrzebniejszych widzialnych, przystąpiono do czytania głośnego tak wyrazów pojedynczych wypisanych na kartach geograficznych, na tytułach książek jako też i tekstu w książce zawartego. (...) Z takim zbiorem wyrazów wychowaniec posłany był do szkoły gimnazjalnej klasy zaczynającej, gdzie uczył się pisać i rachować mechanicznie ${ }^{46}$.

Robiąc stopniowo postępy w mówieniu i odczytywaniu z ust, Piotr Gąssowski wzbudzał zrozumiałe zainteresowanie jako przykład wielkiego osiągnięcia ${ }^{47}$. Szczególnie zostało to zauważone, kiedy w 1808 roku wziął udział w egzaminie gimnazjalnym niższych klas i wykazał się takimi umiejętnościami, że egzaminatorzy powiadomili o tym fakcie Izbę Edukacji Publicznej w Warszawie ${ }^{48}$. Ta z kolei zaprosiła do Warszawy o. Falkowskiego wraz z uczniem, aby mógł zaprezentować swoje osiągnięcia i opisać używaną przez siebie metodę. Miało to miejsce w styczniu 1809 roku $^{49}$.

Nic więc dziwnego, że w Towarzystwie Królewskim Przyjaciół Nauk pojawiła się inicjatywa utworzenia dla polskich głuchoniemych dzieci odpowiedniej szkoły. Ogłaszając 22 grudnia 1809 roku coroczne tematy rozpraw konkursowych z różnych dziedzin nauki, jako czwarty temat komisja ogłosiła konkurs na utworzenie w Warszawie instytutu głuchoniemych ${ }^{50}$. Organizatorzy niewątpliwie liczyli na to, że o. Falkowski przystąpi do niego i podejmie się stworzenia takiej placówki. Tymczasem do konkursu nie zgłosił się ani jeden kandydat, także nie uczynił tego o. Falkowski, zapewne nie czując się jednak na siłach do podjęcia tak poważnego zadania. Tak więc i ta trzecia próba utworzenia szkoły dla polskich głuchoniemych dzieci nie powiodła się.

Jednak do tej trzeciej nieudanej próby historia dopisała dalszy ciąg. Kiedy w maju 1815 roku powstał Rząd Tymczasowy Królestwa Polskiego, a kierownikiem Wydziału Oświecenia Narodowego został Stanisław Kostka Potocki, już w lipcu wezwał do siebie o. Falkowskiego i polecił mu zajęcie się urządzaniem instytutu dla głuchoniemych ${ }^{51}$. Postanowił także skierować o. Falkowskiego, na koszt państwa, do rocznego seminarium nauczycielskiego przy

${ }^{46}$ Tamże, s. 22.

47 L. Karpińska, Zarys dziejów Warszawskiego Instytutu Głuchoniemych i Ociemniatych w latach 1817-1917, [w:] O wychowaniu dzieci głuchych, red. O. Lipkowski, Warszawa 1967, s. 16.

${ }^{48}$ Izba Edukacji Publicznej - centralny urząd administracji publicznej Księstwa Warszawskiego. Istniała w latach 1807-1812, kierował nią Stanisław Kostka Potocki, we współpracy z ks. Stanisławem Staszicem, Samuelem Bogumiłem Lindem, o. Onufrym Kopczyńskim i innymi osobistościami tego okresu. Zadaniem Izby Edukacyjnej był przede wszystkim rozwój szkolnictwa elementarnego. Kilku członków Izby było również członkami wspomnianego wyżej Towarzystwa Królewskiego Przyjaciół Nauk.

${ }^{49}$ H. Okopiński, Zarys dziejów, s. 106.

${ }^{50}$ E. Nurowski, Surdopedagogika, s. 30.

${ }^{51}$ H. Okopiński, Zarys dziejów, s. 107. 
Instytucie Głuchoniemych w Wiedniu (tego samego, które 10 lat wcześniej ukończył ks. Anzelm Zygmunt). O. Falkowski początkowo nie wyrażał zgody, jednak pod naciskiem ks. Stanisława Staszica propozycję przyjął. Pojechał do Wiednia z czterema uczniami, ukończył seminarium, a po powrocie $\mathrm{w} 1816$ roku, za zgodą władz oświatowych, utworzył klasę dla głuchoniemych przy szkole w Szczuczynie ${ }^{52}$. Po roku klasę tę przeniesiono do Warszawy i tak 23 października 1817 roku powstał pod kierownictwem o. Jakuba Falkowskiego Instytut Głuchoniemych, który wkrótce będzie obchodził swoje 200-lecie.

\section{BIBLIOGRAFIA}

Boháček J. i in., Spis židowských rodzin w Čechach z roku 1793, t. 2, Archiwum Państwowe w Pradze.

Dziedzic S., Historia rozwoju szkolnictwa specjalnego w Polsce, [w:] Pedagogika rewalidacyjna, red. A. Hulek, PWN, Warszawa 1977.

Falkowski J., O początkach i postępie Instytutu Warszawskiego Głuchoniemych oraz niektóre jego urządzenia dla wiadomości osób, jakikolwiek związek z Instytutem mieć mogących, Warszawa 1823.

Karpińska L., Zarys dziejów Warszawskiego Instytutu Gtuchoniemych i Ociemniatych w latach 1817-1917, [w:] O wychowaniu dzieci gtuchych, red. O. Lipkowski, PZWS, Warszawa 1967.

Kierzek A., Instytut dla głuchoniemych w Romanowie - pierwszy ośrodek tego typu na ziemiach polskich, Otolaryngologia, 2012, 11(4).

Manczarski A., Instytut Gtuchoniemych w Romanowie na Wotyniu, Szkoła Specjalna, 1935/1936, XII.

Nurowski E., Surdopedagogika polska. Zarys historyczny, PWN, Warszawa 1983.

Okopiński H., Zarys dziejów nauczania głuchoniemych, Państwowy Instytut Pedagogiki Specjalnej, Warszawa 1964.

Szczepankowski B., Ksiądz Anzelm Zygmunt - pierwszy surdopedagog polski, Szkoła Specjalna, 2007, 5 .

Szewczenko W.M., Winikniennia i rozwitok w Ukraini spiecialnich szkił dla głuchonimich u drugij połowini XIX - początku XX stolittia, Institut Specialnoj Piedagogiki NAPN Ukraini, Kijów 2010.

Trębicka-Postrzygacz B., Szkoty dla dzieci niestyszacych na ziemiach polskich w latach 18171914, Towarzystwo Naukowe KUL, Lublin 2011.

Williams H.G., Fyodorova P., The origins of the St. Petersburg Institute for the Deaf, [w:] Looking Back. A Reader of the History of Deaf Communities and their Sign Languages, Signum, Hamburg 1993.

Wolfgang A., Rys historyczny usiłowań w uczeniu głuchoniemych i zakładów na ten cel przeznaczonych, Józef Zawadzki własnym nakładem, Wilno 1830.

${ }^{52}$ Tamże, s. 107-108. 